\title{
AN UNUSUAL TOURMALINE COMPOSITION FROM SITHONIA PENINSULA (NORTHERN GREECE)
}

\author{
Aurisicchio C. ${ }^{1}$, Bartolomei A. ${ }^{2}$, Kyriakopoulos K. ${ }^{3}$, and Magganas A. ${ }^{3}$ \\ ${ }^{1}$ CNR-Istituto di Geoscienze e Georisorse Sezione di Roma, P.le A. Moro 5, 00185 Roma, Italy \\ carlo.aurisicchio@uniromal.it \\ ${ }^{2}$ Università di Firenze, Dipartimento di Scienze della Terra, Via La Pira 4, 50121 Firenze, Italy \\ ${ }^{3}$ National and Kapodistrian University of Athens, Faculty of Geology and Geoenvironment, \\ Department of Mineralogy and Petrology, Panepistimiopolis 157 84, Ano Ilissia, Athens, Greece \\ ckiriako@geol.uoa.gr,amagganas@geol.uoa.gr
}

\begin{abstract}
The variety and wideness of substitutions shown by tourmaline group, mainly in the $Z, Y$ and $X$ sites, make possible a high number of real and hypothetical endmembers. However in some cases it is not so obvious to determine to what endmembers to refer to, but the wide stability field of tourmaline and its occurrence in different geological environments make useful to define the composition as percentages of end-members to trace back to its genesis. In this paper the followed procedure to identify the components of a complex tourmaline is given. During a study on the granitoid intrusions outcropping on Sithonia, Chalkidiki Peninsula (Northern Greece), a swarm of very small crystals of tourmaline, subhedral or more often allotriomorphic, has been found as stuffing of subparallel micro fractures in the quartz core of a pegmatite dike. Their composition, analysed by EMPA, turns out to be rather unusual and not satisfactorily referable to so far proposed solid solutions. It is characterized by remarkable Al deficiency (ZAl $<6$ apfu), high amounts of magnesium and iron with $\mathrm{Mg}>\mathrm{Fe}$ and $\mathrm{Na}$ dominating $\mathrm{X}$ site. On the basis of compositional and crystal-chemical evidences, supported by previous literature, it was hypothesized that $\mathrm{Mg}$ and Fe have to be referred to an uvite feruvite component, while the considerable part of total iron in its trivalent oxidation state yields a povondraitic component according also with $\mathrm{Na}$ in $\mathrm{X}$ site. These data, coupled with a theoretical evaluation of bond valence sum (BVS) that allowed inferring the presence of $\mathrm{OH}$ anions in the $W$ site, make reasonable to consider Sithonia tourmaline as the new variety sodian povondraitic hydroxil uviteferuvite. On the basis of its composition, of its fabric and of the oscillatory trends shown by the main elements of $Y$ and $X$ sites, this tourmaline may be considered post magmatic likely of hydrothermal genesis.
\end{abstract}

Key words: crystal-chemistry, end-members, uvite-feruvite, povondraite, pegmatite.

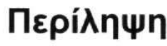

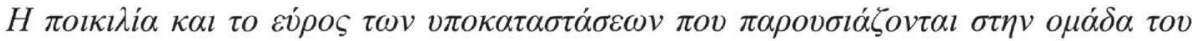

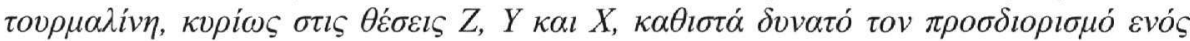

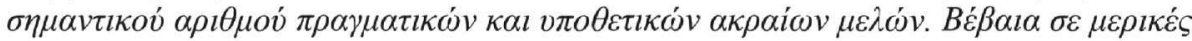




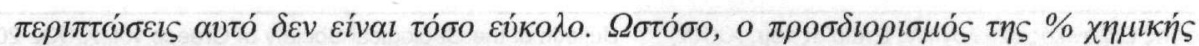

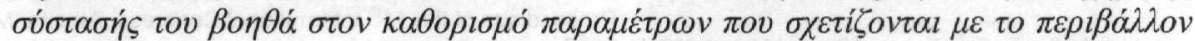

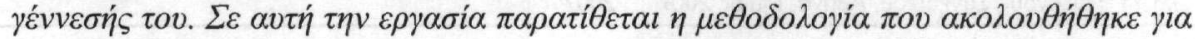

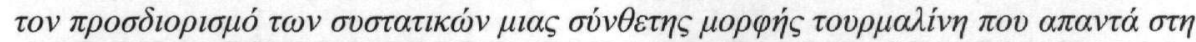

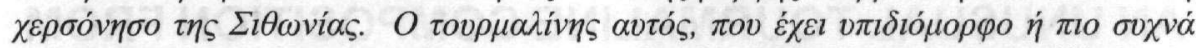

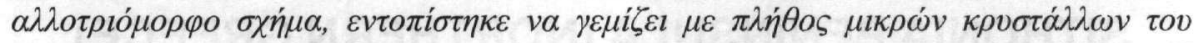

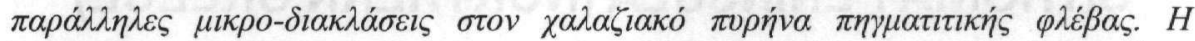

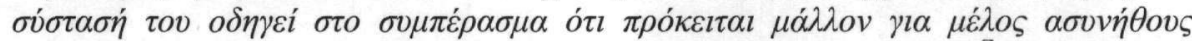

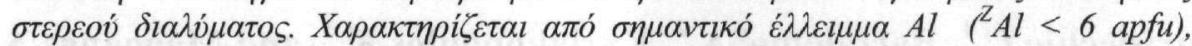

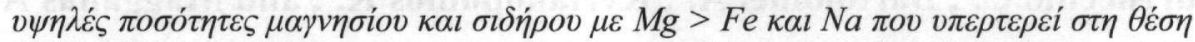

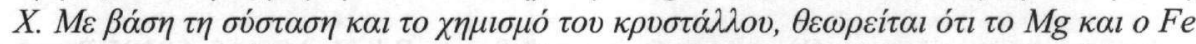

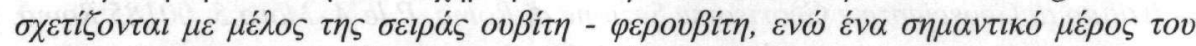

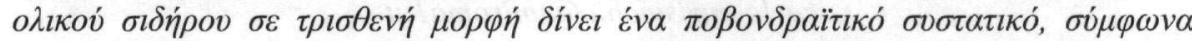

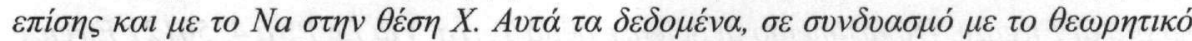

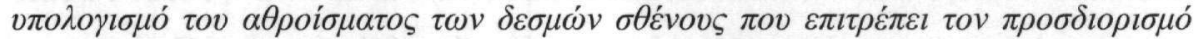

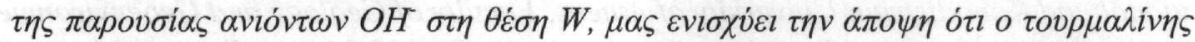

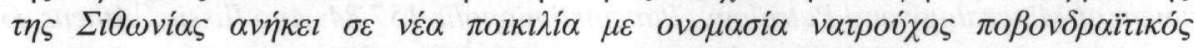

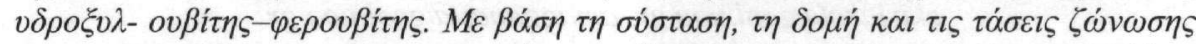

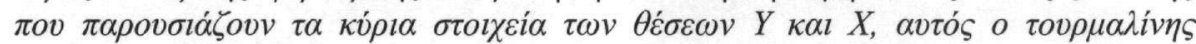

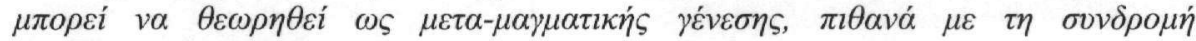

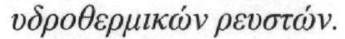

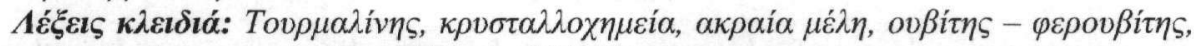
$\pi \circ \beta o v \delta \rho \alpha i ̈ \eta \zeta, ~ \pi \eta \gamma \mu \alpha \tau i \tau \eta \varsigma, ~ \Sigma \imath \theta \omega v i \alpha, ~ E \lambda \lambda \alpha ́ \delta \alpha$.

\section{Introduction}

Tourmaline is a complex cyclosilicate belonging to the hexagonal crystal system, with general formula $\mathrm{XY}_{3} \mathrm{Z}_{6}\left[\mathrm{BO}_{3}\right]_{3}\left[\mathrm{~T}_{6} \mathrm{O}_{18}\right] \mathrm{V}_{3} \mathrm{~W}$. Its variable chemism, frequent zoning, wide stability field P-T, ability to exchange chemical species with coexisting minerals and fluids (Keller et al. 1999) and high strength to exogenous agents make this mineral a potential metallogenetic and petrogenetic indicator in many igneous and metamorphic environments (Manning 1982, Henry and Guidotti 1985, Jolliff et al. 1986, Kassoli-Fournaraki 1990, Farmer and Halls 1993, London and Manning 1995, Henry and Dutrow 1992, 1996).

Tourmaline structure consists of five types of cationic site: $\mathrm{T}$, tetrahedrally coordinated; $\mathrm{B}$, in triangular coordination; $\mathrm{Z}$ and $\mathrm{Y}$, octahedrally coordinated; $\mathrm{X}$, coordinated by nine or ten anions (Selway 1999). Both two octahedral sites and $X$ site are involved in various possible substitutions which give rise to the wide compositional range showed by natural tourmaline.

Usually $\mathrm{Al}$ is the dominant cation in $\mathrm{Z}$ site, sometimes substituted by even considerable amounts of $\mathrm{Mg}, \mathrm{Fe}^{2+}, \mathrm{Fe}^{3+}\left(\mathrm{Fe}^{3+}{ }_{6}=\right.$ oxy-ferri-foitite and oxy-Mg-ferri-foitite), $\mathrm{Cr}\left(\mathrm{Cr}_{6}=\right.$ chromdravite and fluor-chromdravite); since substitutions at $\mathrm{Y}$ site are constrained more by the size of the ions than by their valence (Grice and Ercit 1993), many different cations may dominate it, that is $\mathrm{Li}\left(\mathrm{Li}_{2} \mathrm{Al}=\right.$ liddicoatite and hydroxy-liddicoatite), $\mathrm{Mg}, \mathrm{Fe}^{2+}, \mathrm{Fe}^{3+}, \mathrm{Al}$ and $\mathrm{Cr}\left(\mathrm{MgCr}_{2}=\right.$ oxy-chromdravite $)$ (Hawthorne and Henry 1999), with lesser amounts of Mn, V, Zn (Schmetzer and Bank 1984, Kazachenko et al. 1993).

Several cations may get into X site, mainly occupied by $\mathrm{Na}, \mathrm{Ca}$; moreover, it can be $\mathrm{K}$-dominant (Grice et al. 1993) or show remarkable vacancies (MacDonald et al. 1993, Pezzotta et al. 1996, Selway et al. 1998a, Aurisicchio et al. 1999).

The sites occupied by $\mathrm{Si}$ and $\mathrm{B}$ are subject to moderate chemical substitutions: small amounts of Al substitute for $\mathrm{Si}$ cations in $\mathrm{TO}_{4}$ tetrahedra (Foit and Rosenberg 1977, 1979, Hawthorne 1996). The presence of $\mathrm{B}$ inside $\mathrm{TO}_{4}$ is debatable, some authors assert there is no evidence for its occupation of $\mathrm{Si}$ tetrahedral site, whereas recently Ertl et al. (2006) describe tourmaline 
containing IVB from several localities. The presence of substantial IV B is limited to, or more common in, Al-rich tourmalines.

The anions occurring in $\mathrm{V}$ and $\mathrm{W}$ sites allow defining if the observed phase is an oxy, a hydroxy or a fluoritic term: $\mathrm{V}$ site is usually filled by $\mathrm{OH}^{-}$, rarely by $\mathrm{O}^{2-}$; W site may be occupied by $\mathrm{O}^{2-}, \mathrm{OH}^{-}$ or $\mathrm{F}^{-}$.

Two main mechanisms of substitution can occur in tourmaline: the first one involves changes of cations having the same oxidation state inside the same crystallographic site (i.e. ${ }^{\mathrm{Y}} \mathrm{Mg} \leftrightarrow{ }^{\mathrm{Y}} \mathrm{Fe}^{2+}$ ); the second one involves changes of heterovalent cations between different sites (i.e. ${ }^{\mathrm{X}} \mathrm{Ca}+{ }^{\mathrm{Z}} \mathrm{Mg} \leftrightarrow{ }^{\mathrm{X}} \mathrm{Na}$ $+{ }^{\mathrm{Z}} \mathrm{Al}$ ) (Henry and Guidotti 1985).

Tourmaline composition was currently expressed on the basis of its end-members dravite, schorl and elbaite. However, the analytical method evolution and the new impulse given to researches on this mineral due to its genetic significance showed remarkable deviations and the opportunity to consider new end-members for every possible succession in the three tourmaline groups: alkali, calcic and X-vacant (Hawthorne 1999).

In this work, we discuss the features and the genetic inferences of small tourmaline grains occurring in pegmatitic dykes cutting metamorphic rocks of the Circum-Rhodope Belt, an isopic zone of the internal Hellenides, and related to the nearby granitic intrusions of Sithonia peninsula. The tourmalines studied occur within the dykes as swarms of clusters, composed by small grains or mostly tiny subhedral crystals, showing under microscope evidences of cracks, rarely slight traces of bending, homogeneous distribution of the color (parallel polars) and a sharp pleochroism from pale yellow to deep green. Both the granular aggregates and the subhedral crystals show similar composition.

\section{Geological Environment}

The Sithonia Peninsula, the middle extension of Peninsula (Northern Greece), is occupied by rocks belonging to the Circum-Rhodope Belt (CRB) and the Serbo-Macedonian Massif (SMM). The $\mathrm{CRB}$ is mostly covered by the Sithonia pluton, an elongated Eocene intrusion, and in lesser extent by a Permian to Jurassic flysch of the Svoula Group, by Mid-Jurassic Ophiolites, and by the Chortiatis Unit (Fig. 1) consisting of greenschists, gneisses, metadiorites and marbles (Kauffman et al. 1976, Kockel et al. 1977). The SMM rocks of the area include the Palaeozoic metamorphic

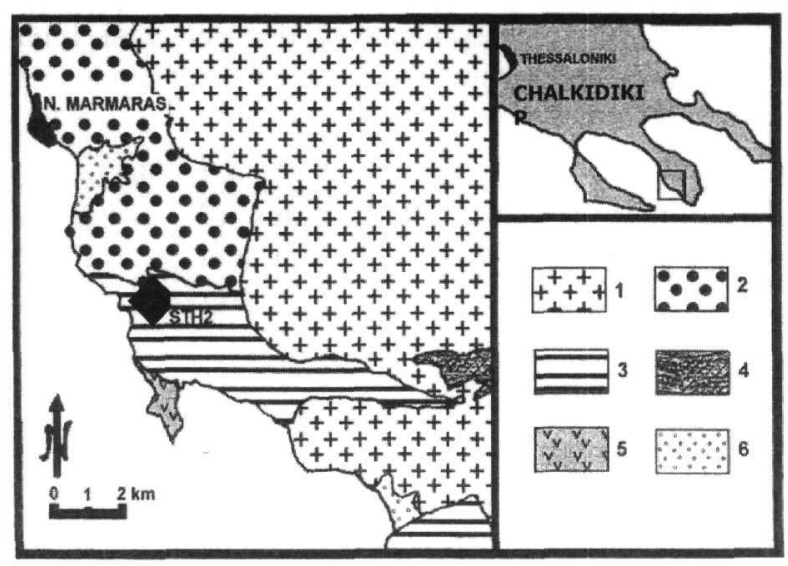

Figure 1 - Schetch map of part of the Sithonia peninsula showing sample (STH2) location. 1.

Sithonia pluton; 2. Svoula flysch; 3. Choriatis Unit; 4.Vertiskos Series; 5. Ophiolites; 6. Quaternary. rocks of the Vertiskos Series (Fig. 1) (Kockel et al. 1977).

The Sithonia pluton displays irregular shape and follows the NW-SE regional structural trend. In many places, particularly at the margins of the pluton, a clearly oriented fabric and cataclastic texture can be observed, very probably related to a regional deformative and metamorphic event. The intrusive body comprises moderately peraluminous to metaluminous rocks; the geochemical features suggest processes of fractional crystallization and crustal contamination for the genesis of the Sithonia pluton (Christophides et al. 1990). 
The ophiolitic rocks and the Chortiatis Unit rocks have been deformed and regionally metamorphosed in the upper greenschist to amphibolite facies mainly during Upper Jurassic to Lower Cretaceous. Retrograde metamorphic events have been also recognized (Mussallam and Jung 1986, Kassoli-Fournaraki 1990).

Aplitic and pegmatitic veins cut both intrusive and country metamorphic rocks.

The samples taken for this study are representative of a dyke cross-cutting gneissic rocks of the Chortiatis Unit in the central area of the peninsula (Fig. 1).

\section{Experimental}

Chemical compositions were determined in the Sezione di Roma of the Institute of Geosciences and Georesources of the CNR, using a Cameca CX 827 Electron Microprobe, equipped with three wavelength-dispersive (WDS) and one energy-dispersive (EDS) Link-System spectrometers, which are running simultaneously.

Selected crystals have been analyzed for a definite group of elements distinctive of tourmaline, among which only $\mathrm{Si}, \mathrm{Al}, \mathrm{Na}, \mathrm{Ca}, \mathrm{Mg}, \mathrm{Fe}$, Ti and $\mathrm{Mn}$ exceed instrumental detection limits. Compositional homogeneity was verified within single crystals and between crystals belonging to different swarms, to specify eventual chemical variations.

Operating conditions were $15 \mathrm{KV}$ accelerating voltage, $20 \mathrm{nA}$ beam current and $2 \mu$ beam diameter. Wavelength spectrometers were used for all analyzed elements; element peaks and background were measured with counting times of 10 seconds each. A synthetic diopside glass was used as a reference material for $\mathrm{Si}$ (TAP), $\mathrm{Ca}$ (PET) and $\mathrm{Mg}$ (TAP); a jadeite crystal for Al (TAP) and Na (TAP); a rutile crystal for Ti (PET); a Norway fayalite for Fe (LIF); rhodonite for Mn (LIF); a Durango apatite for F (TAP); orthoclase for K (PET). Matrix correction was calculated by using the $\varphi(\rho Z)$ method (Pouchou and Pichoir 1984, 1985).

EMP analyses representative of compositions of both granular aggregates and subhedral crystals are reported in Table 1, together with the number of atoms per formula unity (apfu) calculated on the basis of $31(\mathrm{O}, \mathrm{OH})$, assuming stoichiometric amounts of $\mathrm{OH}^{-}$and $\mathrm{B}$. The assumption $\mathrm{B}=3$ apfu is sustained by several authors (Grice et al. 1993, Hawthorne et al. 1993, Selway et al. 1998) and seems to be satisfactorily correct. Assessment of water content also could be well represented by the formula $\mathrm{OH}=4$ apfu (MacDonald et al. 1993, Selway et al. 1998). The Li content was obtained on the basis of the formula: $3-\Sigma Y$. Fluorine was always under detection limits. Crystallographic sites have been filled partially following previous works (Grice and Ercit 1993, Frietsch et al. 1997) and as indicated by some clear correlations.

In order to estimate the $\mathrm{Fe}^{2+}$ tot $/ \mathrm{Fe}^{3+}$ tot ratio, we imposed the saturation of $\mathrm{Si}$ tetrahedral site ( $\mathrm{Si}=6.000 \mathrm{apfu}$ ). Using Grice and Ercit (1993) formula the number of $\mathrm{Mg}$ atoms at $\mathrm{Y}$ site has been calculated; $Z$ site has been saturated to 6.000 apfu with any remaining $\mathrm{Mg}$ ions and Fe considered as $\mathrm{Fe}^{3+}$ (Frietsch et al. 1997).

\section{Mineral Chemistry Data and Discussion}

The Sithonia tourmaline is characterized by $\mathrm{Al}$ deficiency $(\mathrm{Al}<6.0$ apfu), abundance of $\mathrm{Mg}$ coupled with high $\mathrm{Fe}$ and prevalence of $\mathrm{Na}$ in $\mathrm{X}$ site; it has an unusual composition, seldom occurring in tourmaline literature, ascribed by some authors to mere dravitic members (Grice and Ercit 1993) or as povondraitic oxy-dravite (Henry et al. 1999).

Considering Table 1, Al content is never sufficient to fill the octahedral $\mathrm{Z}$ site, whereas $\mathrm{Y}$ site occupancy is greater than 3 apfu as was expected considering that some $\mathrm{Mg}$ and/or Fe should enter $\mathrm{Z}$ site to fill it. $\mathrm{Mg}$ ranges from 1.749 to $2.032 \mathrm{apfu}$, always exceeding $\mathrm{Fe}^{2+}$ tot which ranges from 
Table 1 - Representative EMP analyses of Sithonia tourmaline

\begin{tabular}{|c|c|c|c|c|c|c|c|c|c|c|c|c|c|}
\hline & 1 & 2 & 3 & 4 & 5 & & Rim ext & Rim & Rim & Core & Rim & Rim & Rim opp \\
\hline $\mathrm{SiO} 2$ & 36,78 & 36,45 & 36,67 & 36,10 & 36,49 & $\mathrm{SiO}_{2}$ & 36,50 & 36,33 & 36,18 & 36,35 & 36,26 & 36,53 & 36,27 \\
\hline Ti02 & 0,29 & 0,00 & 0,32 & 0,64 & 0,22 & $\mathrm{TiO}_{2}$ & 0,56 & 0,52 & 0,56 & 0,14 & 0,12 & 0,21 & 0,32 \\
\hline B203* & 10,54 & 10,42 & 10,48 & 10,37 & 10,37 & $\mathrm{~B}_{2} \mathrm{O}_{3}$ & 10,57 & 10,52 & 10,48 & 10,54 & 10,51 & 10,58 & 10,51 \\
\hline $\mathrm{Al} 203$ & 29,67 & 29,32 & 28,96 & 28,28 & 27,70 & $\mathrm{Al}_{2} \mathrm{O}_{3}$ & 27,51 & 27,44 & 27,50 & 27,47 & 27,02 & 29,71 & 29,28 \\
\hline $\mathrm{Fe} 0$ & 7,59 & 8,76 & 9,46 & 10,44 & 11,37 & $\mathrm{Fe}^{*}$ & 3,31 & 3,97 & 5,07 & 3,83 & 1,90 & 5,32 & 6,73 \\
\hline $\mathrm{MnO}$ & 0,00 & 0,15 & 0,00 & 0,00 & 0,00 & $\mathrm{Fe}_{2} \mathrm{O}_{3}^{*}$ & 7,23 & 6,37 & 5,34 & 7,84 & 9,71 & 4,00 & 2,79 \\
\hline $\mathrm{MgO}$ & 8,12 & 7,51 & 7,24 & 7,27 & 7,45 & $\mathrm{MnO}$ & 0,00 & 0,00 & 0,00 & 0,00 & 0,06 & 0,08 & 0,11 \\
\hline $\mathrm{CaO}$ & 0,58 & 0,61 & 0,84 & 0,91 & 0,54 & $\mathrm{Mg} 0$ & 7,66 & 7,74 & 7,78 & 7,50 & 7,26 & 6,94 & 7,17 \\
\hline $\mathrm{Na} 2 \mathrm{O}$ & 2,61 & 2,56 & 2,54 & 2,44 & 2,64 & $\mathrm{CaO}$ & 0,97 & 0,96 & 0,96 & 0,45 & 0,46 & 0,60 & 0,80 \\
\hline Li20** & 0,22 & 0,19 & 0,29 & 0,08 & 0,07 & $\mathrm{Na}_{2} \mathrm{O}$ & 2,09 & 2,31 & 2,31 & 2,45 & 2,43 & 2,40 & 2,40 \\
\hline $\mathrm{F}$ & 0,00 & 0,00 & 0,00 & 0,00 & 0,00 & $\mathrm{Li}_{2} \mathrm{O}$ & 0,57 & 0,52 & 0,39 & 0,44 & 0,67 & 0,43 & 0,28 \\
\hline $\mathrm{H} 20^{* * *}$ & 3,63 & 3,60 & 3,61 & 3,58 & 3,58 & F & 0,00 & 0,00 & 0,00 & 0,00 & 0,00 & 0,00 & 0,00 \\
\hline \multirow[t]{2}{*}{ Total } & 100,04 & 99,56 & 100,40 & 100,11 & $100,4]$ & $\mathrm{H}_{2} \mathrm{O}$ & 3,65 & 3,63 & 3,62 & 3,63 & 3,62 & 3,65 & 3,62 \\
\hline & & & & & & Total & 100,62 & 100,31 & 100,19 & 100,64 & 100,03 & 100,47 & 100,29 \\
\hline \multicolumn{14}{|c|}{ Ions number on the basis of $31(0,0 \mathrm{H}, \mathrm{F})$} \\
\hline $\mathrm{Si}$ & 6,067 & 6,079 & 6,084 & 6,048 & 6,117 & \multicolumn{8}{|c|}{ Ions number on the basis of $31(0,0 \mathrm{H}, \mathrm{F})$} \\
\hline B & 3,000 & 2,999 & 3,000 & 3,000 & 3,000 & $\mathrm{Si}$ & 6,000 & 6,001 & 5,999 & 5,998 & 5,998 & 6,001 & 6,000 \\
\hline Altot & 5,770 & 5,765 & 5,665 & 5,586 & 5,474 & B & 3,000 & 3,000 & 3,000 & 3,000 & 3,000 & 3,000 & 3,000 \\
\hline $\mathrm{Al}(\mathrm{T})$ & 0,000 & 0,000 & 0,000 & 0,000 & 0,000 & Al tot & 5,332 & 5,343 & 5,376 & 5,345 & 5,269 & 5,754 & 5,710 \\
\hline $\operatorname{Al}(Z)$ & 5,770 & 5,765 & 5,665 & 5,586 & 5,474 & $\mathrm{Al}(\mathrm{T})$ & 0,000 & 0,000 & 0,000 & 0,000 & 0,000 & 0,000 & 0,000 \\
\hline $\mathrm{Al}(\mathrm{Y})$ & 0,000 & 0,000 & 0,000 & 0,000 & 0,000 & $\operatorname{Al}(\mathrm{Z})$ & 5,332 & 5,343 & 5,376 & 5,345 & 5,269 & 5,754 & 5,710 \\
\hline $\mathrm{Fe} 2+$ & 1,047 & 1,222 & 1,312 & 1,463 & 1,593 & $\operatorname{Al}(Y)$ & 0,000 & 0,000 & 0,000 & 0,000 & 0,000 & 0,000 & 0,000 \\
\hline $\mathrm{Mn}$ & 0,000 & 0,021 & 0,000 & 0,000 & 0,000 & $\mathrm{Fe}^{2+}$ & 0,455 & 0,548 & 0,703 & 0,529 & 0,263 & 0,731 & 0,931 \\
\hline Mgtot & 1,996 & 1,867 & 1,791 & 1,814 & 1,860 & $\mathrm{Fe}^{3+}$ & 0,894 & 0,792 & 0,666 & 0,974 & 1,209 & 0,494 & 0,347 \\
\hline $\operatorname{Mg}(Z)$ & 0,230 & 0,235 & 0,335 & 0,414 & 0,526 & $\mathrm{Mn}$ & 0,000 & 0,000 & 0,000 & 0,000 & 0,009 & 0,011 & 0,016 \\
\hline $\operatorname{Mg}(Y)$ & 1,767 & 1,632 & 1,455 & 1,400 & 1,334 & $\mathrm{Mg}$ tot & 1,877 & 1,905 & 1,923 & 1,845 & 1,790 & 1,700 & 1,768 \\
\hline $\mathrm{Ti}$ & 0,036 & 0,000 & 0,039 & 0,080 & 0,027 & $\operatorname{Mg}(Z)$ & 0,668 & 0,657 & 0,624 & 0,655 & 0,731 & 0,246 & 0,290 \\
\hline $\mathrm{Li}$ & 0,149 & 0,127 & 0,192 & 0,056 & 0,044 & $\operatorname{Mg}(Y)$ & 1,208 & 1,249 & 1,298 & 1,190 & 1,059 & 1,454 & 1,478 \\
\hline$Y$ tot & 2,999 & 3,001 & 2,999 & 3,000 & 2,999 & $\mathrm{Ti}$ & 0,069 & 0,065 & 0,070 & 0,017 & 0,015 & 0,026 & 0,040 \\
\hline \multirow[t]{2}{*}{$Z+Y$ tot } & 8,999 & 9,001 & 8,999 & 9,000 & 8,999 & $\mathrm{Li}$ & 0,374 & 0,345 & 0,262 & 0,290 & 0,446 & 0,284 & 0,188 \\
\hline & & & & & & $Y$ tot & 3,001 & 2,999 & 3,000 & 3,000 & 3,001 & 3,001 & 3,000 \\
\hline $\mathrm{Ca}$ & 0,103 & 0,109 & 0,149 & 0,164 & 0,097 & $Z+Y$ tot & 9,001 & 8,999 & 9,000 & 9,000 & 9,001 & 9,001 & 9,000 \\
\hline $\mathrm{Na}$ & 0,835 & 0,828 & 0,818 & 0,791 & 0,856 & & & & & & & & \\
\hline \multirow[t]{2}{*}{$X$ tot } & 0,937 & 0,937 & 0,967 & 0,955 & 0,953 & $\mathrm{Ca}$ & 0,171 & 0,170 & 0,171 & 0,080 & 0,082 & 0,106 & 0,142 \\
\hline & & & & & & $\mathrm{Na}$ & 0,666 & 0,740 & 0,743 & 0,784 & 0,779 & 0,765 & 0,770 \\
\hline $\mathrm{OH}$ & 3,999 & 4,000 & 3,999 & 4,000 & 4,000 & $X$ tot & 0,837 & 0,910 & 0,913 & 0,864 & 0,861 & 0,871 & 0,912 \\
\hline $\mathrm{F}$ & 0,000 & 0,000 & 0,000 & 0,000 & 0,000 & & & & & & & & \\
\hline \multirow[t]{3}{*}{$\mathrm{OH}+\mathrm{F}$} & 3,999 & 4,000 & 3,999 & 4,000 & 4,000 & $\mathrm{OH}$ & 4,000 & 4,000 & 4,000 & 4,000 & 4,000 & 4,000 & 4,000 \\
\hline & & & & & & $\mathrm{F}$ & 0,000 & 0,000 & 0,000 & 0,000 & 0,000 & 0,000 & 0,000 \\
\hline & & & & & & $\mathrm{OH}+\mathrm{F}$ & 4,000 & 4,000 & 4,000 & 4,000 & 4,000 & 4,000 & 4,000 \\
\hline
\end{tabular}

Total Iron as $\mathrm{FeO}$.

*calculated on the assumption of $3 \mathrm{~B}$ atoms per formula unit.

${ }^{* *}$ calculated as $\mathrm{Li}=3-($ Ycations sum)

$* * *$ calculated as $\mathrm{OH}+\mathrm{F}=4$
Table 2 - EMP chemical analyses of a single tourmaline crystal

1.050 tc $1.597 \mathrm{apfu}$. Mn is usually under the instrumental detection limits, while Ti sometimes reaches 0.14 apfu. Calculated $\mathrm{Li}$ is never greater than $0.15 \mathrm{apfu}$, as expected for ferro-magnesian compositions.

Tetrahedral T-site always shows a considerable excess of Si cations (Table 1); this repeated result has been confirmed by rigorous checks through the execution of numerous analyses over different crystals and within single crystals and using different reference standards, in order to display Qmicro-inclusions effect and eventual instrumental errors. This excess, as consequence, could be considered consistent with the existence of trivalent cations in the tourmaline structure. 

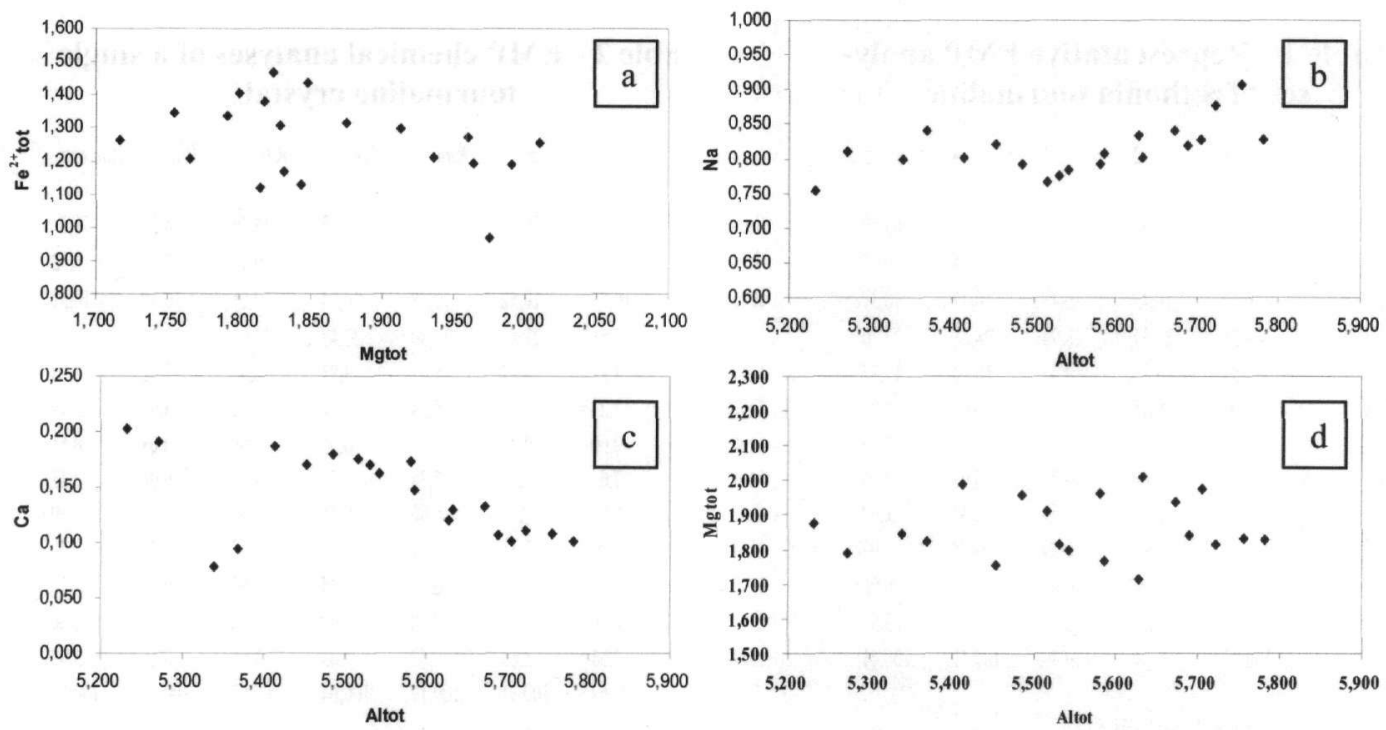

Figure 2 - Linear correlations between the main elements (apfu) of Sithonia tourmaline: (a) $\mathrm{Fe}^{2+}$ tot vs. $\mathrm{Mg}_{\text {tot }}$; (b) $\mathrm{Na}$ vs. $\mathrm{Al}_{\text {tot }}$; (c) Ca vs. $\mathrm{Al}_{\text {tot }}$; (d) $\mathrm{Mg}_{\text {tot }}$ vs. $\mathrm{Al}_{\text {tot }}$

$\mathrm{X}$-site is dominated by $\mathrm{Na}$, followed by lesser amounts of $\mathrm{Ca}$. Small vacancies are frequent.

The following linear correlations between the main elements allow to visualize the Sithonia tourmaline behavior: $\mathrm{Fe}^{2+}$ tot $\mathrm{vs}$. $\mathrm{Mg}_{\text {tot }}$ shows oscillations around a trend slightly negative (Fig. 2a); a light positive correlation links $\mathrm{Na}$ to $\mathrm{Al}_{\text {tot }}$ (Fig. 2b), whereas $\mathrm{Ca}$ and $\mathrm{Al}_{\text {tot }}$ give a good negative correlation (Fig. 2c); moreover, $\mathrm{Mg}$ shows steady values for all $\mathrm{Al}_{\text {tot }}$ contents (Fig. 2d).
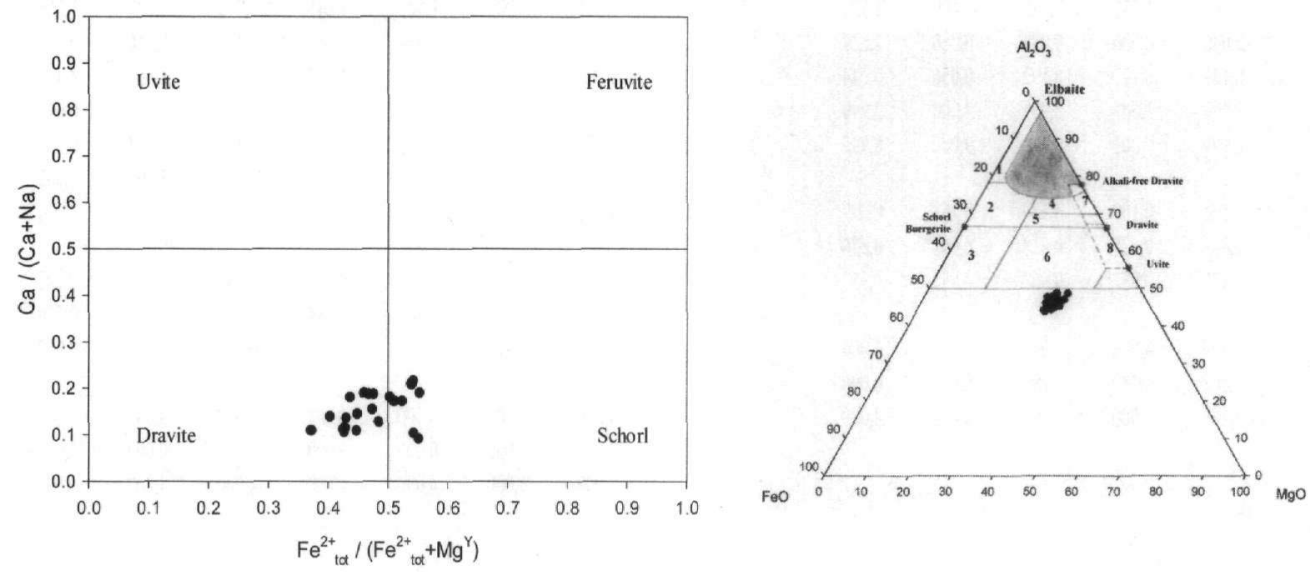

Figure 3 - (a) Plot of $\mathrm{Ca} /(\mathrm{Ca}+\mathrm{Na})$ at the $\mathrm{X}$ site vs. $\mathrm{Fe} /(\mathrm{Fe}+\mathrm{Mg})$ at the $\mathrm{Y}$ site. (b) $\mathrm{Al}-\mathrm{Fe}_{\text {tot }}-$ Mg diagram (in molecular proportions) for tourmaline from various rock types: field \#6 defines the compositional range of tourmaline from $\mathrm{Fe}^{3+}$-rich quartz-tourmaline rocks, calcsilicate rocks and metapelites (Henry and Guidotti 1985)

The diagrams of Fig. 3 ( $a$ and b) represent an attempt for the classification of Sithonia tourmaline on the basis of the correlation $\mathrm{Ca} /(\mathrm{Ca}+\mathrm{Na})$ vs. $\mathrm{Fe}_{\text {tot }} /\left(\mathrm{Fe}_{\text {tot }}+\mathrm{Mg}\right)$ given by Selway et al. (1998) and the compositional fields defined in the triangular plot $\mathrm{Al}_{2} \mathrm{O}_{3}-\mathrm{MgO}-\mathrm{FeO}$ proposed by Henry and Guidotti (1985). In Fig. 3a the studied compositions fall on the boundary line between schorl and dravite end-members, with a light prevalence of dravite. The triangular diagram of Fig. $3 \mathrm{~b}$ shows the area covered by Sithonia compositions: they fall below the $\mathrm{Al}_{50}-(\mathrm{Fe}, \mathrm{Mg})_{50}$ line. 
However, the reported graphic representations of the chemical compositions of Sithonia tourmaline do not seem to be fully representative of these phases, since do not show meaningful trends and do not allow to point out the Al behavior, nor to define any specific field for such compositions. Nevertheless, the triangular diagram of Fig. 3b suggests the presence of a possible considerable $\mathrm{Fe}^{3+}$ amount, since they fall just below the field \#6 of the triangle reported by Henry and Guidotti (1985) and assigned to $\mathrm{Fe}^{3+}$-rich quartz-tourmaline rocks, to calcium-silicate rocks and to metapelite. This hypothesis may be further confirmed by the optical observations carried out on our samples. In fact, tourmaline containing significant amounts of Fe with mixed valences $(2+$ and $3+)$ exhibits very strong optical absorption and pleochroism due to intervalence charge transfer (Mattson and Rossman 1987), as in the case of Sithonia tourmaline.

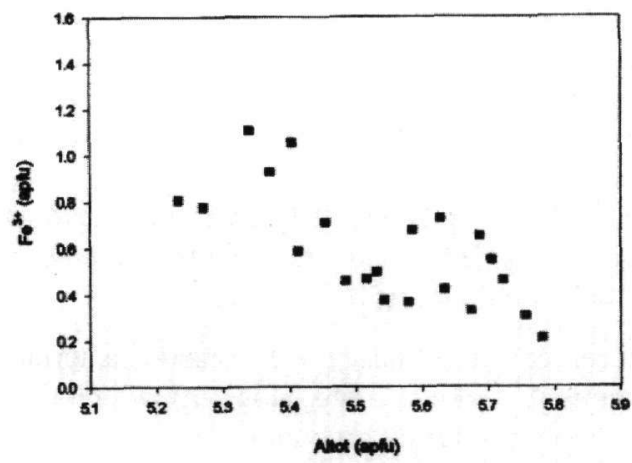

Figure 4 - Tendency of calculated $\mathrm{Fe}^{3+}$ $v s$. $\mathbf{A l}_{\text {tot }}$ showing a negative correlation $(a p f u)$

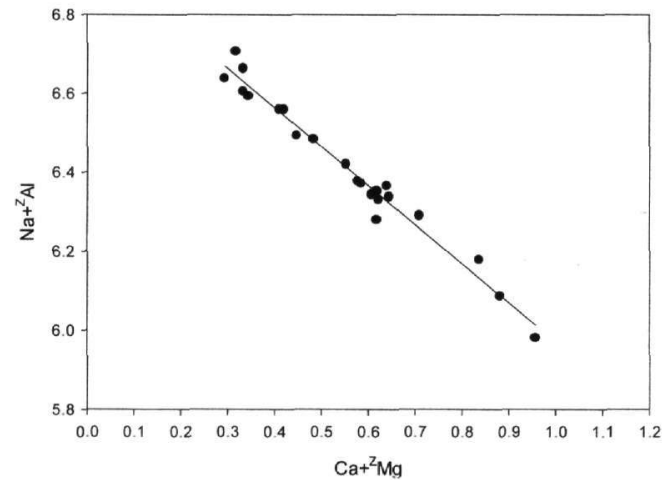

Figure 5 - Negative correlation $\mathrm{Na}+\mathrm{Al}(\mathrm{Z})$ vs. $\mathrm{Ca}+\mathrm{Mg}(\mathrm{Z})$, representing the uvitic substitution (apfu)

To quantify the amount of $\mathrm{Fe}^{3+}$ the $\mathrm{Fe}^{2+}{ }_{\text {tot }} / \mathrm{Fe}^{3+}$ tot ratio was evaluated, using an iterative program, which carries out $\mathrm{Fe}_{\text {tot }}$ division imposing a stoichiometric amount of $\mathrm{Si}=6.000$ apfu. In Table 2 the analyses of a single tourmaline crystal have been recalculated following the above procedure.

Using the formula proposed by Grice and Ercit (1993), based on the hypothesis of an ideal solid solution at $\mathrm{Y}$ site between $\mathrm{Fe}$ and $\mathrm{Mg}$ for tourmaline compositions with $\mathrm{FeO}_{\text {tot }}$ greater than $7 \%$, it was possible to determine the number of $\mathrm{Mg}$ atoms at $\mathrm{Y}$ site, with any remaining $\mathrm{Mg}$ assigned to $\mathrm{Z}$. Often the calculated ${ }^{\mathrm{Z}} \mathrm{Mg}$ is not enough to fill $Z$ site and vacancies continues to exist which have been saturated with the necessary amount of $\mathrm{Fe}^{3+}$ to reach 6.000 apfu.

The goodness of this choice, to partially fill $\mathrm{Z}$-site with $\mathrm{Fe}^{3+}$, is confirmed by the good negative trend $\mathrm{Fe}^{3+}$ vs. $\mathrm{Al}_{\text {tot }}$ (Frietsch et al. 1997) of Fig. 4; the excellent negative trend of Fig. 5 shows the uvitic substitution $\mathrm{Na}+{ }^{\mathrm{Z}} \mathrm{Al} \leftrightarrow$ $\mathrm{Ca}+{ }^{\mathrm{Z}} \mathrm{Mg}$. Moreover, the Manning (1982) diagram points out transitional compositions toward uvite end-member perfectly following substitution mechanism line (Fig. 6). So, the seemingly simple solid solution schorldravite reveal the existence also of an

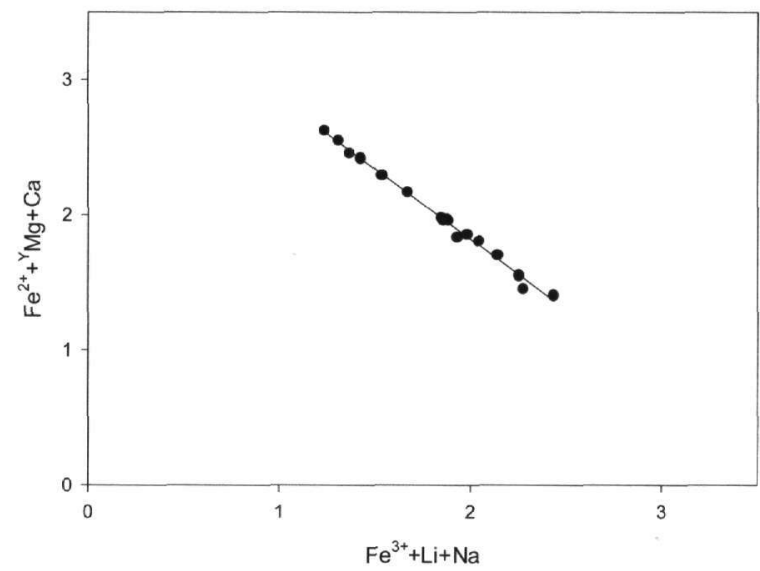

Figure 6 - The complex substitution mechanism $\mathrm{Fe}^{3+}+\mathrm{Na}+\mathrm{Li} \leftrightarrow \mathrm{Mg}(\mathrm{Y})+\mathrm{Ca}+\mathrm{Fe}^{2+}$, controlling the transition povondraite $\rightarrow$ uvite-feruvite (apfu) 
uvitic component, as from the entrance of Ca substituting $\mathrm{Na}$ in $\mathrm{X}$ site proceeding toward lesser $\mathrm{Al}$ contents, with always high $\mathrm{Mg}_{\text {tot }}$.

Assuming the $\mathrm{Al}$ amount as indicator of compositional and thermal evolution, it is known that Alricher tourmaline crystallize during magmatic and pegmatitic stages, while Al-poor terms have been observed in the later hydrothermal stage (London and Manning 1995, Trumbull and Chaussidon 1999), Sithonia tourmaline crystallized in a Fe-Mg rich and Al-poor environment, according with the fluorine content always under the electron microprobe detection limits, which, coupled with the decrease of T, should expand the stability field of tourmaline toward lower B and Al content (London 1999).

The recorded $\mathrm{Fe}^{3+}$ contents are variable but increasing for decreasing $\mathrm{Al}$ (Table 2), therefore while tourmaline growth evolves from schorl-dravite toward the uvitic end-member, the oscillatory trend of $\mathrm{Fe}^{3+}$-rich component is the result of a fluctuating increase of the oxydation degree of hydrothermal fluids. Because of the increase of oxygen fugacity, the transition from simple schorldravite to more complex solid solution could be combined also with the substitution of $\mathrm{OH}^{-}$with $\mathrm{O}^{2-}$ in W site. A theoretical evaluation of Bond Valence Sum (BVS), utilizing ionic radii values of Shannon (1976) and Brown and Wu formula (1976), with the updating of Brown (1987), allows confirming the predominant $\mathrm{OH}^{-}$presence in $\mathrm{W}$ site, consistently with the results obtained by Grice and Ercit (1993) for similar tourmaline compositions on the basis of X-ray data.

In order to emphasize the significant chemical features of these phases, we consider a ternary diagram functional to support the new reading-key, that is $\mathrm{Al}_{6}-\mathrm{Fe}^{3+}{ }_{6}-\mathrm{Mg}_{6}$ (Fig. 7a), which three vertices describe $\mathrm{Z}$ occupancy: the first $\mathrm{Al}_{6}$ indicates the $\mathrm{Al}$ saturation amount both in dravite and schorl end-members; the second $\mathrm{Fe}^{3+}{ }_{6}$ the $\mathrm{Fe}^{3+}$ saturation amount in an oxy-Mg-ferrifoitite and an oxy-ferrifoitite, while $\mathrm{Mg}_{6}$ is the $\mathrm{Mg}$ amount in a hypothetical term in which $\mathrm{Mg}$ entirely fills Zsite. For the sake of clearness, in the same diagram some Z-compositions are plotted, representative of tourmaline end-members particularly useful to display Sithonia tourmaline behavior: the representative points of Sithonia tourmaline fall near the line jointing the top vertex $\mathrm{Al}_{6}$ with $\mathrm{MgAl}_{5}$ point corresponding with $\mathrm{Z}$ occupancy of (hydroxy)uvite, (hydroxy)feruvite and oxy-dravite. The diagram shows that the Al deficiency causes a shift towards "uvite" composition, because the existence of an oxy-dravitic component can be excluded owing to $\mathrm{Al}(\mathrm{Y})$ absence. Moreover, the $\mathrm{F}$ absence in the analyses leaves out $\mathrm{Mg} \mathrm{Al}_{5}$ point represents compositions with $\mathrm{F}$ anions in W-site (i.e. ideal uvite and feruvite).
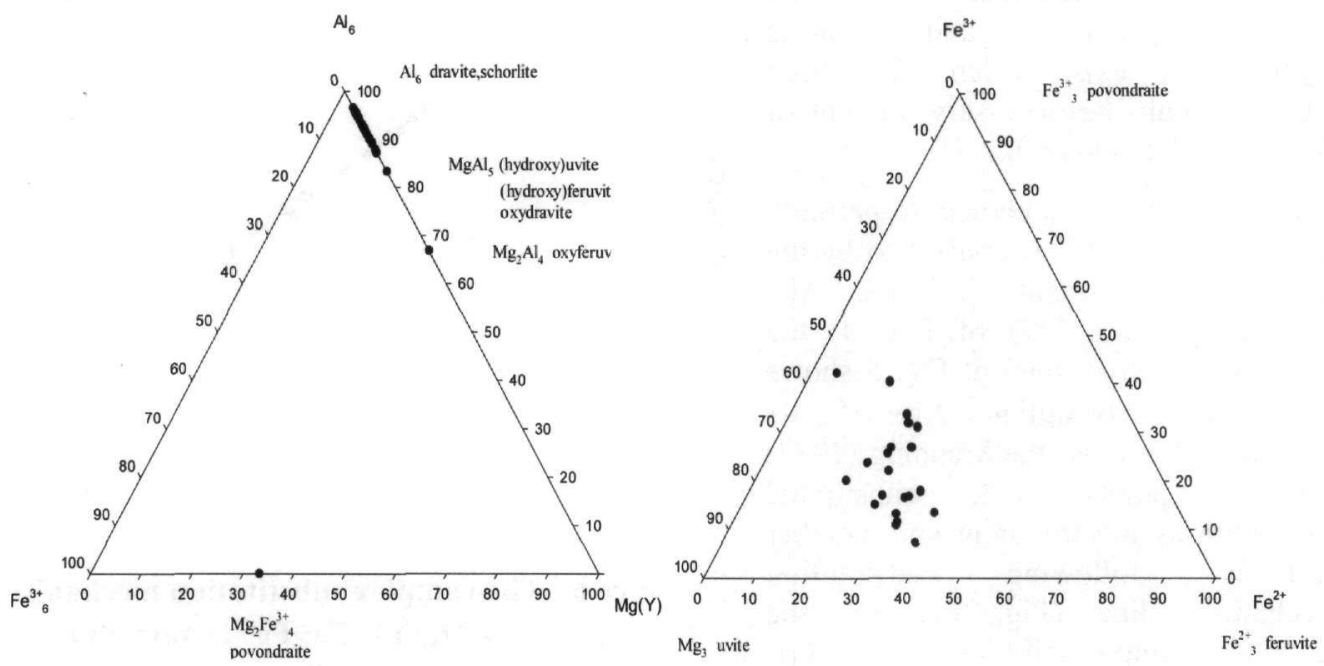

Figure 7 - (a) Triangular diagram $\mathrm{Al}_{6}-\mathrm{Fe}^{3+}{ }_{6}-\mathrm{Mg}_{6}$, describing $\mathrm{Z}$-site occupancy, (b) Triangular diagram $\mathrm{Fe}_{3}^{3+}-\mathrm{Mg}(\mathrm{Y})_{3}-\mathrm{Fe}_{3}^{2+}$, showing the cohexistence of the three components 
In the light of the above, we can consider Sithonia compositions as schorl-dravite containing an uvitic and a $\mathrm{Fe}^{3+}$-rich component. The triangular diagram of $\mathrm{Fig}$. $7 \mathrm{~b}$, which vertices represent the saturation amounts of $\mathrm{Fe}^{3+}$ ( $\mathrm{Fe}^{3+}$-rich end-member), $\mathrm{Mg}$ (dravite) and $\mathrm{Fe}^{2+}$ (schorl) in $\mathrm{Y}$-site, defines the compositional field of this solid solution.

The small dimensions of tourmaline crystals, together with their exclusive occurrence as subparallel veinlets, as well as their complex composition characterized by $\mathrm{Fe}_{\text {tot }} / \mathrm{Mg}_{\text {tot }}$ ratio $<1$ (Power 1968, Fieremans and De Paepe 1982, Taylor and Slack 1984, London and Manning 1995, Trumbull and Chaussidon 1999), suggest that tourmaline crystallized during a hydrothermal stage, in subsolidus conditions, as confirmed by ${ }^{\mathrm{Y}} \mathrm{Al}$ absence (London and Manning 1995) and by $\mathrm{Al}$ deficiency in $Z$ site. The low degree of alkali-site vacancies (Trumbull and Chaussidon 1999) allows drawing similar inferences on the crystallization of Sithonia tourmaline.

\section{Conclusions}

- Compositions as Sithonia tourmaline, before considered as simple dravite-schorlite solid solutions or povondraitic oxy-dravite, turn out to be a more complex phase, characterized by deficiency of $\mathrm{Al}$ in $\mathrm{Z}$-site and predominance of $\mathrm{Mg}_{\text {tot }}$ over $\mathrm{Fe}_{\text {tot }}$, with $\mathrm{Na}$ over $\mathrm{Ca}$ in $\mathrm{X}$ site. This composition seems to refer to an uncommon combination of several actual and hypothetical end-members.

- The hypothesis of a hydrothermal origin is further on supported by the finely oscillatory trends, distinctive of a growth from rapidly changing fluids. The several peaks of $\mathrm{Fe}^{3+}$ within its negative oscillatory trend versus $\mathrm{Al}_{\text {tot }}$ could be referred to different and more and more oxydized fluid rising (Cavarretta and Puxeddu 1990).

- The variations of the chemical-physical parameters produced a fine-scale zonation of crystals, reflected by continual trend inversions (London 1999). At this state, lacking isotopic studies, it is not possible any claim about the origin of fluids: true metamorphic or with a magmatic component. However, a strong metamorphic contribution seems to be preferred on the basis of micro-structural and geological observations, i.e. the bending traces under the microscope and the gneissic rocks surrounding the quartz-tourmaline dyke; moreover, we cannot avoid to remark that hydrothermal tourmaline, containing high $\mathrm{Mg}$, usually occurs in veins hosted in metasedimentary rocks (Smith and Yardley 1995).

\section{Acknowledgments}

Authors thank S.A.R.G. of University of Athens for covering part of the field work expenses. An anonymous reviewer is also thanked.

\section{References}

Aurisicchio, C., Ottolini, L., and Pezzotta, F., 1999. Electron- and ion-microprobe analyses and genetic inferences of tourmalines of the foitite-schorl solid solution, Elba Island (Italy), Eur. J. Mineral., 11, 217-225.

Brown, I.D., 1987. Recent Developments in the Bond Valence Model of Inorganic Bonding, Physics and Chemistry of Minerals, 15, 30-34.

Brown, I. D., and Wu, K.K., 1976. Empirical parameters for calculating cation-oxygen bond valences, Acta Cryst., B 32, 1957-1959. 
Christofides, G., D’Amico, C., Del Moro, A., Eleftheriadis, G., and Kyriakopoulos, C., 1990. $\mathrm{Rb} / \mathrm{Sr}$ geochronology and geochemical characters of the Sithonia plutonic complex (Greece), Eur. J. Mineral., 2, 79-87.

Ertl, A., Hughes, J.M., Prowatke, S., Ludwig, T., Pinnelli, S.R. Prasad, Brandstatter, F., Korner, W., Schuster, R., Pertlik, F., and Marschall, H., 2006. Tetrahedrally coordinated boron in tourmalines from the liddicoatite-elbaite series from Madagascar: Structure, chemistry, and infrared spectroscopic studies, Am. Min., 91, 1847-1856.

Farmer, C.B., and Halls, C., 1993. Paragenetic evolution of cassiterite-bearing lodes at South Crofty Mine, Cornwall, UK. In Y.T. Maurice (ed.), Proc. of the Eighth Quadriennal IOAGOD Symposium, Ottawa, Canada, Aug. 12-18, 1990. E. Schweizerbart'sche Verlagsbuchhandlung, Stuttgart, 365-381.

Fieremans, M., and De Paepe, P.D., 1982. Genesis of tourmalinites from Belgium: petrographical and chemical evidence, Mineralogical Magazine, 46, 95-102.

Foit, F.F., Jr., and Rosenberg, P.E., 1977. Coupled substitutions in the tourmaline group, Contributions, to Mineralogy and Petrology, 62, 109-127.

Foit, F.F., Jr., and Rosenberg, P.E., 1979. The structure of vanadium-bearing tourmaline and its implications regarding tourmaline solid solutions, Am. Mineral., 64, 788-798.

Frietsch, R., Tuisku, P., Martinsson O., and Perdahl, J.A., 1997. Early Proterozoic Cu-(Au) and Fe ore deposits associated with regional $\mathrm{Na}-\mathrm{Cl}$ metasomatism in northern Fennoscandia, Ore, Geology Reviews, 12, 1-34.

Grice, J.D., and Ercit, T.S., 1993. Ordering of Fe and Mg in the tourmaline crystal structure: The correct formula, Neues Jahrbuch Miner. Abh., 165(3), 245-266.

Grice, J.D., Ercit, T.S., and Hawthorne, F.C., 1993. Povondraite, a redefinition of the tourmaline ferridravite, Am. Mineral., 78, 433-436.

Hawthorne, F.C., 1996. Structural mechanisms for light-element variations in tourmaline, The Canadian Mineralogist, 34, 123-132.

Hawthorne, F.C., and Henry, D.J., 1999. Classification of the minerals of the tourmaline group, Eur. J. Mineral., 11, 201-215.

Hawthorne, F.C., MacDonald, D.J., and Burns, P.C., 1993. Reassignment of cation site occupancies in tourmaline: $\mathrm{Al}-\mathrm{Mg}$ disorder in the crystal structure of dravite, Am. Mineral., $78,265-270$.

Henry, D.J., and Dutrow, B.L., 1992. Tourmaline in a low grade clastic metasedimentary rocks: an example of the petrogenetic potential of tourmaline, Contrib. Mineral. Petrol., 112, 203218.

Henry, D.J., and Dutrow, B.L., 1996. Metamorphic Tourmaline and its petrological applications. In E.S. Grew, and L.M. Anovitz (eds), Boron, Mineralogy, Petrology and Geochemistry. Mineral. Soc. Am. Rev. Mineral., 33, 503-557.

Henry, D.J., and Guidotti, C.V., 1985. Tourmaline as a petrogenetic indicator mineral: an example from the staurolite-grade metapelites of NW Maine, Am. Mineral., 70, 1-15.

Henry, D.J., Kirkland, B.L., and Kirkland, D.W., 1999. Sector-zoned tourmaline from the cap rock of a salt dome, Eur. J. Mineral., 11, 263-280.

Jolliff, B.L., Papike, J.J., and Shearer, C.K., 1986. Tourmaline as a recorder of pegmatite evolution: Bob Ingersoll pegmatite, Black Hills, South Dakota, Am. Min. 71,472-500. 
Kassoli-Fournaraki, A., 1990. Metabasic dikes in the southeastern part of the Chortiatis series (Northern Greece): petrology and P-T conditions of metamorphism. Schweiz, Mineral. Petrogr. Mitt., 70, 437-447.

Kauffman, G., Kockel, F., and Mollat, H., 1976. Notes on the stratigraphic and paleogeographic position of the Svoula formation in the Innermost zones of the Hellenides (Northern Greece), Bull. Soc. Geol. France, 18, 225-230.

Kazachenko, V.T., Butsik, L.A., Sapin, V.I., Kitaev, I.V., Barinov, N.N., and Narnov , G.A., 1993. Vanadian-chromian tourmaline and vanadian muscovite in contact-metamorphosed carbonaceous rocks, Primorye, Russia, The Canadian Mineralogist, 31, Part.2, 347-356.

Keller, P., Roda Robles, E., Pesquera Pérez, A., and Fontan, F., 1999. Chemistry, paragenesis and significance of tourmaline in pegmatites of the Southern Tin Belt, central Namibia, Chemical Geology, 158, 203-225.

Kockel, F., Mollat, H., and Walter, H., 1977. Erlauterungen zur geologischen Karte der Chalkidiki und angrenzender Gebiete 1:100.000 (Nord Griechenland). Hannover. London, D. (1999): Stability of tourmaline in peraluminous granite systems: the boron cycle from anatexis to hydrothermal aureoles, Eur. J. Mineral., 11, 253-262.

London, D., and Manning, D.A.C., 1995. Compositional variations and significance of tourmaline from south-west England, Econ. Geol., 90, 495-519.

MacDonald, D.J., Hawthorne, F.C., and Grice, J.D., 1993. Foitite, $\square\left[\mathrm{Fe}^{2+}{ }_{2}\right.$ $\left.\left(\mathrm{Al}, \mathrm{Fe}^{3+}\right)\right] \mathrm{Al}_{6} \mathrm{Si}_{6} \mathrm{O}_{18}\left(\mathrm{BO}_{3}\right)_{3}(\mathrm{OH})_{4}$, a new alkali-deficient tourmaline: Description and crystal structure, Am. Mineral., 78, 1299-1303.

Manning, D.A.C., 1982. Chemical and morphological variation in tourmalines from the Hub Kapong batholith of peninsular Thailand, Mineralogical Magazine, 45, 139-147.

Mattson, S.M., and Rossman, G.R., 1987. $\mathrm{Fe}^{2+}-\mathrm{Fe}^{3+}$ interactions in tourmaline, Phys. Chem. Minerals, 14, 163-171.

Mussallam, K., and Jung, D., 1986. Petrology and geotectonic significance of salic rocks preceding ophiolites in the eastern Vardar Zone, Greece, Tschermacks Min. Petr. Mitt., 35, 217-242.

Pezzotta, F., Hawthorne, F.C., Cooper, M.A., and Teerstra, D.K., 1996. Fibrous foitite from San Piero in Campo, Elba, Italy, The Canadian Mineralogist, 34, 741-744.

Pouchou, J.L., and Pichoir, F., 1984. A new model for quantitative analysis. I. Application to the analysis of homogeneous samples, La recherche Aérospatiale, 3, 13-38.

Pouchou, J.-L., and Pichoir, F., 1985. "PAP" $\varphi(\rho Z)$ procedure for improved quantitative microanalysis, Microbeam Anal.- 1985, San Francisco Press, San Francisco, California, 104-106.

Power, G.M., 1968. Chemical variation in tourmalines from south-west England, Mineralogical Magazine, 36, 1078-1089.

Schmetzer, K., and Bank, H., 1984.Crystal chemistry of tsilaisite (manganese tourmaline) from Zambia, N. Jahr. Mineral. Mitt., 1984(2), 61-69.

Selway, J., 1999. PhD Thesis, University of Manitoba, Winnipeg, Manitoba, Canada

Selway, J.B., Cerny, P., and Hawthorne, F.C., 1998. Feruvite from lepidolite pegmatites at Red Cross Lake, Manitoba, The Canadian Mineralogist, 36, 433-439. 
Shannon, R.D., 1976. Revised Effective Ionic Radii and Systematic Studies of Interatomic Distances in Halides and Chalcogenides, Acta Cryst., A32, 751-766.

Taylor, B.E., and Slack, J.F., 1984. Tourmalines from Appalachian-Caledonian massive sulfide deposits: textural, chemical and isotopic relationships, Econ. Geol., 79, 1703-1726.

Trumbull, R.B., and Chaussidon, M., 1999. Chemical and boron isotopic composition of magmatic and hydrothermal tourmalines from the Sinceni granite-pegmatite system in Swaziland, Chemical Geology, 153, 125-137. 